\title{
Entrepreneurial Growth Aspirations and Familiarity with Economic Development Organizations: Evidence from Canadian Firms
}

\author{
Angelo Dossou-Yovo ${ }^{1}$
}

\begin{abstract}
The purpose of this paper is to investigate the relationship between the entrepreneurship ecosystem and the entrepreneur's willingness to grow. This study is particularly interested in exploring the relationship between entrepreneur's familiarity with the key economic development organizations in the entrepreneurship ecosystem and the willingness to grow. Several studies have investigated the growth process in small and medium sized enterprises (SMES) since the case has been made that high growth SMEs contribute to economic growth through job creation. To date, these studies have identified multiple internal and external determinants including their effects on small business growth. There is evidence in the literature that characteristics of the entrepreneurs such as the willingness to grow and the entrepreneur's network are important factors in growth process. However, the relationship between growth process and the entrepreneur's networking behavior is yet to be fully understood. Drawing from the entrepreneurship ecosystem literature, the growth process literature and the resource dependence theory, this study uses the business confidence survey from 2011 to 2013, which targeted all businesses across all of Halifax Regional Municipality (HRM) in Nova Scotia, Canada, to explore the relationship between the entrepreneur willingness to grow and the propensity to network with key economic development organizations of the entrepreneurial ecosystem. The findings support the assumption that the proportion of businesses that are willing to grow (i.e. hire additional staff and enter new markets within the next twelve months) is higher for the group of businesses that are familiar with the key economic development organizations than for the group of businesses that are not familiar with them. However, the results are not homogeneous across all populations. Our findings also indicate that the higher the expectation to enter new markets over the next twelve months, the higher the odds to be familiar with the key economic development organizations. Our findings contribute to the literature around the association between networking and small business growth.
\end{abstract}

1 Angelo Dossou-Yovo, Ph.D., PMP, Dalhousie Rowe School of Business, 6100 University Avenue, Halifax, NS, Canada, B3H 4R2; angelo.dossou-yovo@dal.ca. 
Keywords: growth process, small business, entrepreneurial ecosystem, networking, Canada

\section{INTRODUCTION}

For many decades, policy makers have been looking for effective economic policies to boost economic growth. Since it has been demonstrated that the entrepreneurial system is a key driver of economic growth (Spilling, 1996), policies have shifted to focus on entrepreneurs and small and medium-sized enterprises (SMEs), especially high growth SMEs which are known for their high share of job creation (Storey and al., 1988). These small businesses are also called 'gazelles' as they grow rapidly (i.e. annual growth rate of $20 \%$ or higher) but they represent between 3 to $5 \%$ of the population of small businesses (Birch, 1987). In order to increase the number of 'gazelles', public policy makers are now embracing the entrepreneurship ecosystem approach as an alternative to the transactional form of support (Mason \& Brown, 2014). Mason and Brown argue that public policies that use a holistic approach (Isenberg, 2010) and which focus on the environment, represented as the entrepreneurship ecosystem, are more effective than transactional forms of support such as financial assistance. Although external factors, such as the entrepreneurship ecosystem, influence small business growth, there is also evidence in the literature that characteristic of the entrepreneur such as his/her willingness to grow (Davidsson 1989, Kolvereid, 1990, Gundry \& Welsch, 1997; Cooper et al., 1994) is an important factor in growth process. One of the important factors for a thriving entrepreneurship ecosystem is the presence of entrepreneurs, but those that can identify and exploit unique and scalable opportunities which translate into high value creation such as wealth for the business and jobs.

The purpose of this paper is to investigate the relationship between the entrepreneurship ecosystem and the entrepreneur's willingness to grow. This paper presents the results of the preliminary stage of a broader research project about the process of small business growth. In this study, the main research question is: Does the entrepreneur's willingness to grow affect familiarity with key actors in the entrepreneurial ecosystem such as economic development organizations? We are assuming that the entrepreneur that is willing to grow would start networking (i.e. developing relationships) with key economic development organizations in order to get access to the external resources (for instance the business support services) for growth. Although other studies have investigated the small business growth process and have identified multiple internal (e.g. Barkham et al., 1996; Baum \& Locke, 2004; Baum \& al, 2001; Birley \& Stockley, 2000; 
Chandler \& Janse, 1992; Davidson, 1991) and external determinants (e.g. Becchetti \& Trovato, 2002; Chandler \& Hanks, 1994); very few studies, to our knowledge, have investigated the determinants by combining internal and external factors.

This study uses the case of Halifax Regional Municipality (HRM) located in the province of Nova Scotia (Canada). The region of Halifax is the most densely populated region with a population of 414,398 whereas the total population of the province is 942,668 (Statistics Canada, 2014). The province of Nova Scotia currently faces several challenges such as a shrinking population and a declining economy. Halifax metropolitan area is the main economic driver of Nova Scotia which faces many economic challenges including the growth of small and medium enterprises. The majority of the businesses are small and medium sized and the lack of available jobs make it difficult to refrain the young people from moving out of the province. According to the definition of Statistics Canada, a small business has between 1 to 99 employees whereas a medium sized business has between 100 to 499 employees. The growth of small and medium enterprises (SME) is a priority for public authorities as they generate most of the jobs compared to large companies.

The rest of the paper is organized as follows. In section 2, the literature on entrepreneurship ecosystem, the process of small business growth and the resource dependency perspective are reviewed and then we hypothesized a relationship between the entrepreneur willingness to grow and familiarity with the key economic development organizations of the entrepreneurship ecosystem. In section 3, we describe the data and the methodology used in this paper, then, in the following section, we present the results of the analyses that have been undertaken to explore our hypotheses. The discussion of the results along with the conclusions and implications for managers of the key economic development organizations and policymakers are presented in the last section of this paper.

\section{ENTREPRENEURSHIP ECOSYSTEM, ECONOMIC DEVELOPMENT ORGANIZATIONS AND THEIR FUNCTIONS}

\section{Definition and components}

The entrepreneurship ecosystem is a concept that has been brought forward in the literature recently. According to Vogel $(2013$, p.7) the term ecosystem was originally introduced by ecologists and subsequently by James Moore in his article published during the 1990s in Harvard Business review (Mason \& Brown, 2014, p.5). There are a number of definitions available in the literature. For the purpose of our study, we use the definition of Mason 
and Brown (2014) which have been suggested as a synthesis of the existing definitions in the literature.

Entrepreneurship ecosystem is "[...] a set of interconnected entrepreneurial actors (both potential and existing), entrepreneurial organizations (e.g. firms, venture capitalists, business angels, banks), institutions (universities, public sectors agencies, financial bodies) and entrepreneurial processes (e.g. the business birth rate, number of high growth firms, level of 'blockbuster entrepreneurship', number of serial entrepreneurs, degree of sell-out mentality within firms and levels of entrepreneurial ambition) which formally and informally coalesce to connect, mediate and govern the performance within the local entrepreneurial environment" (Mason \& Brown, 2014, p. 5).

Several models have been suggested to conceptualize the entrepreneurial ecosystem. Isenberg (2010) has suggested a model which consists of 13 essential elements that can be used as a framework to assess the entrepreneurship ecosystem. The essential elements are as follows: public leaders, governments, culture, visible success stories, knowledge people, capital sources, nonprofits and industry associations, educational institutions, public infrastructures, geographic location, formal and informal groups, venture-oriented professionals and potential customers. Vogel (2013) proposed a similar framework to assess the effectiveness of an entrepreneurship ecosystem. He organized this framework into components and subcomponents, namely: non-entrepreneurship-specific level (government and regulations, geographic location, markets), entrepreneurship-specific level (financing, culture, visibility, support, education, networks) and entrepreneurial actors (novice and social entrepreneurs). In their study of the components of the entrepreneurship ecosystem that influence the development of hightechnology entrepreneurial activity at Boulder, Colorado, Neck and al. (2004) have found that the components, such as incubator organizations, spin-offs, informal and formal networks, the physical infrastructure, and the culture collectively play an important role. These different aforementioned models integrate a set of actors that play an important role in the development of an entrepreneurship ecosystem. The next section will take a closer look at the actors and their roles which we conceptualize further as functions, with the use of the system approach.

\section{Actors and functions}

The components of the entrepreneurship ecosystem suggested by several authors (Neck and al., 2004; Vogel, 2013; Cohen, 2006; Isenberg, 2010) include a group of actors that provide specific resources which contribute to 
its growth. These actors are generally located in the same region and are the suppliers of key resources that influence the growth of the entrepreneurship ecosystem.

The resources accessible in the entrepreneurship ecosystem are as follows:

- information and financial support are available through informal connections with friends, families, colleagues and others (informal network),

- knowledge and other forms of support are available through connections and collaboration with universities, public agencies, economic development organizations and large corporations,

- professional and support services are available through collaboration with lawyers, accountants, consultants, suppliers, etc.,

- sources of capital are provided by venture capitalists and angel investors.

The entrepreneurship ecosystem, although a new approach, incorporates many of the themes of the regional innovation system literature (Masson \& Brown, 2014, p.7). Using the system approach, the entrepreneurial ecosystem can be considered as a system with a group of actors (components) that play specific roles (functions) which collectively maintain and improve the health of the overall system.

In the region of Halifax, which is our focus of study, the economic development organizations are among the key actors. These actors are: The Greater Halifax Partnership, Nova Scotia Business Incorporated, Department of Economic and Rural Development and Tourism, The Atlantic Canada Opportunities Agency.

- Greater Halifax Partnership (GHP) is a public-private partnership including over 135 private investors, which was created in 1996 in order to face the economic challenges of the province. Its mandate is to keep and grow existing businesses. GHP's main activities include business retention and expansion, immigration, trade development, business recruitment, business research and building confidence. GHP, through its Smart Business program, offers a range of services to businesses that include connections to partners such as recruiting and training experts, to research and development institutions, and to other partners that can contribute to business expansion and growth. GHP has also a team that provide advisory services or incentives to stay, especially for businesses that may leave Halifax.

- Nova Scotia Business Incorporated (NSBI) is a crown corporation created in 2001 by the Nova Scotia Incorporated Act. Its mandate is to support economic growth through (a) business development, retention and expansion, (b) the establishment of new businesses in the province, (c) trade operation to connect businesses in the province 
with new markets or new trade opportunities (Crown Corporations business plan 2015-2016, p.45). NSBI fulfills its mandate through collaborations with regional enterprise networks, municipalities, Greater Halifax Partnership, chambers of commerce, businesses, universities and other public agencies. NSBI provides business advisory services to local businesses that are looking to expand their operations either through the development of a new product/service or market expansion. NSBI also offers financial support to cover part of the travel expenses and other costs to participate in international trade shows and conferences.

- The Department of Economic and Rural Development and Tourism (ERDT) is a provincial government body with the mission 'to provide strategic leadership and advice, to enhance collaboration with partners and stakeholders in economic and community development, and tourism, and to create the right conditions for entrepreneurship and businesses to grow and prosper across Nova Scotia' (ERDT Statement of mandate 2014-2015, p.5). ERDT provides funding support to businesses through its Job fund. The government of Nova Scotia has announced on April 9th, 2015 the replacement of ERDT with a new department of business.

- The Atlantic Canada Opportunities Agency (ACOA) is a federal government body that was created in 1987 to provide economic development services in all four provinces in the Canadian Atlantic region. ACOA provides services to businesses through a variety of programs that support business innovation and growth. The Atlantic Innovation Fund provides funding support to businesses in order facilitate joint product development and commercialization of new products with universities, colleges and other research universities. The business development program provides funding support for starting and expanding a business.

Table 1 summarized the main functions of business development organizations that contribute to small business growth.

Table 1. The main functions of business development organizations that contribute to small business growth

\begin{tabular}{ll}
\hline Organizations & Functions contributing to business growth \\
$\begin{array}{l}\text { Greater Halifax } \\
\text { Partnership }\end{array}$ & $\begin{array}{l}\text { Recruitment services and connections with partners (local and } \\
\text { international) }\end{array}$ \\
NSBI & $\begin{array}{l}\text { Business advisory services, and financial support for market } \\
\text { expansion }\end{array}$ \\
ERDT & $\begin{array}{l}\text { Funding support } \\
\text { ACOA }\end{array}$ \\
\hline
\end{tabular}




\section{The entrepreneur's growth aspirations, networking behavior, and resource mobilization}

Small businesses generally grow organically (Davidson et al. 2005) and need to mobilize key resources in the process. An empirical study conducted by Jarillo (1989) found that fast growing firms use more external resources than their competitors. In addition, they gain access to the external resources for growth through networking. Lewis and Churchill (1987) proposed a model of small business growth which consists of five stages: existence, survival, success, take-off and resources maturity. During growth process, eight factors will influence the outcomes. The first four are as follows: financial resources, personal resources, system resources and business resources. The remaining four are related to the owner and are as follows: goals for himself/herself and for the business, his/her operational abilities, his/her managerial ability and willingness to delegate, and his/her strategic abilities. Storey (1994) also found that internal factors such as the characteristics of the entrepreneur, the characteristics of the small business and the development strategies, have an impact on growth outcomes. Other studies have also showed the importance of external (e.g. Becchetti \& Trovato, 2002; Chandler \& Hanks, 1994) and internal factors (e.g. Barkham et al., 1996; Baum \& Locke, 2004; Baum \& al., 2001; Birley \& Stockley, 2000; Chandler \& Janse, 1992; Davidsson, 1991) during the process of growth. The characteristic of the entrepreneurs such as his/her willingness to grow (Davidsson 1989, Kolvereid, 1992, Gundry \& Welsch, 1997; Cooper et al., 1994) is an important factor in the growth process.

Since fast growing small businesses rely on external resources, the external environment is therefore an important factor. Drawing from the resource dependence theory, the business environment can be considered as a reservoir of resources for small business growth. In their seminal paper, "The external control of organizations: a resource dependence perspective", Pfeffer and Salancik (1978) introduced the resource dependency theory as an alternative to the rational model of organization and organizational design. The resource dependency perspective views the organization as an entity that is dependent upon its environment for critical resources. The survival of organizations depends on their ability to not only attract the scarce resources in their environment but also develop strategies to gain control over the resources. Such goal can be achieved through coalitions and collaborations with other organizations, which involve giving up independence to acquire the key resources (raw materials, labor, capital, equipment, knowledge and markets). Firms such as small businesses are vulnerable to resources shortage in their early growth stage. They can enhance their prospects for survival 
when they get support from their environment and if the founders are able to build partnerships and alliances (Garnsey, 1998).

The growth process starts with the willingness of the entrepreneur to grow and to network with actors in the entrepreneurial ecosystem. In our study, the willingness to grow refers to the expectations to introduce a new product/service, or to increase sales, or to hire additional staff, or to invest in new facilities/equipment, or to enter new markets within the next twelve months. In addition, we consider the entrepreneurship ecosystem as the reservoir of resources available through the functions realized by different actors. Therefore, it is reasonable to expect that the proportion of businesses that are willing to grow would be higher for the group that is familiar with the key economic organizations than for the group that is not familiar with them, under the assumption that familiarity with the economic development actors facilitates access to the key external resources for growth. In our study, we are focusing on four key economic development organizations (GHP, NSBI, ERDT, ACOA). Thus, we state the following hypotheses to test the relationship between familiarity with the key economic organizations and the willingness to grow:

H1: There is a relationship between familiarity with GHP (or NSBI or ERDT or ACOA) and the expectations to introduce a new product or service, or to increase sales, or to hire additional staff, or to invest in new facilities/ equipment, or to enter new markets within the next twelve months.

H2: The proportion of businesses that expect to introduce a new product or service, or to increase sales, or to hire additional staff, or to invest in new facilities/equipment, or to enter new markets within the next twelve months is higher for the group of businesses that are familiar with GHP (or NSBI, or ERDT, or ACOA).

\section{RESEARCH METHODS}

\section{Sample}

The data used in this study come from the business confidence surveys, which were administered by a private consultant on behalf of the Greater Halifax Partnership. The survey is administered by telephone twice a year (two waves) during the periods of Spring and Autumn. The trained interviewers take 15 minutes to complete each interview. A total number of 350 interviews were completed for each wave out of 3357 telephone numbers attempted. The current study focuses on four waves that cover the periods from 2011 to 2013. The data to be used in this article represent 1400 companies (see 
Table 2 for the number of respondents per wave). All companies surveyed are located in the region of Halifax and belong to a very broad range of industries.

Table 2. The number and sex of respondents per survey wave

\begin{tabular}{clcccc}
\hline & & \multicolumn{4}{c}{ Wave } \\
\cline { 3 - 6 } & & 2011 Autumn & 2012 Spring & 2012 Autumn & 2013 Spring \\
\hline \multirow{3}{*}{ Gender } & Male & 214 & 222 & 205 & 202 \\
& Female & 136 & 128 & 145 & 148 \\
& Subtotal & 350 & 350 & 350 & 350 \\
\hline
\end{tabular}

The data have been collected by categories and the dataset reports the number of counts for each category; therefore, multivariate technique was not appropriate. We conducted a series of contingency table analyses, then we used a binary logistic regression model to explore the association between the variables of interest. We were then able to test the null hypothesis that there is no association between familiarity with GHP (NSBI, ERDT, ACOA) and the expectations to introduce a new product or service, to increase sales, to hire additional staff, to invest in new facilities or equipment and to enter new markets within the next twelve months. The contingency table analysis method is appropriate to test the association between two categorical variables (Agrestic \& Kateri, 2011; Conniver, 1980).

\section{VARIABLES AND ANALYSES}

In order to analyze the association between familiarity with the key economic development organizations and the willingness to grow, we considered the expectations to introduce a new product or service, to increase sales, to hire additional staff, to invest in new facilities or equipment and to enter new markets within the next twelve months. All these variables are related to growth indicators such as sales, assets, physical output, employment, market share and profits that are among the most frequently used in the literature dealing with the measure of growth (Davidson et al. 2005). The variable Familiarity with a key economic development organization indicates the level of awareness of its existence, its mandate and the business support services available for small businesses.

In the first step, we conducted a series of contingency table analyses for each organization with the columns representing respectively familiarity with the key economic development organization (i.e. GHP, NSBI, ERDT, ACOA) and the rows representing respectively the expectations to introduce a new product or service, to increase sales, to hire additional staff, to invest in new facilities or equipment and to enter new markets within twelve months. 
In the second step, we used a binary logistic regression model considering familiarity with key economic development organizations as dependent variable and the willingness to grow as independent variable.

\section{Potential limitations}

Like any other research, this study has its limitations due to the constraints associated with the dataset. The data were collected per wave and there was no systematic follow up with previous respondents. This implies that a longitudinal study is not appropriate. In addition, we are dealing with categorical data, therefore we are limited in the number of options available to do further analysis of the data. Other limitations are related to the sample size and to the fact that the primary data are self- reported. Finally, the measure used for the willingness to grow does not necessary capture the overall picture. Although this research provides some good insights on the subject of study, further research such as a qualitative study would contribute to validate our findings.

\section{RESULTS}

\section{Test of associations}

Firstly, we conducted a series of contingency table analyses using the sample from all waves. Secondly, we conducted the same analyses separately for each wave to find out if the results vary over time.

The findings from the first series of contingency table analyses (see Tables 3 and 4) indicate that there is no association between familiarity with all key economic development organizations (GHP, NSBI, ACOA, ERDT) and the expectation to introduce a new product or service, to increase sales and to make a major investment in facilities or equipment. The results were not significant; therefore, the null hypothesis cannot be rejected. We came to the same conclusions concerning the association between familiarity with GHP, ACOA and ERDT and the expectation to hire more staff except for NSBI (See Table 4). An association between familiarity with NSBI and the expectation to hire additional staff was found (Chi-square $=4.269 ; \mathrm{P}<0.05$ ). The findings from Table 3 indicate that the proportion of the firms that expect to hire additional staff is higher in the case of the firms that are familiar with NSBI (61.4\%) than in the case of those that are not familiar with NSBI (55.8\%). 
Table 3. Familiarity with economic development organizations and growth aspirations - number of responses

\begin{tabular}{|c|c|c|c|c|c|c|c|}
\hline & & \multicolumn{2}{|c|}{$\begin{array}{l}\text { Familiarity with } \\
\text { GHP }\end{array}$} & \multicolumn{2}{|c|}{$\begin{array}{l}\text { Familiarity with } \\
\text { NSBI }\end{array}$} & \multicolumn{2}{|c|}{$\begin{array}{l}\text { Familiarity with } \\
\text { ACOA }\end{array}$} \\
\hline & & $\begin{array}{l}\text { Not fa- } \\
\text { miliar }\end{array}$ & $\begin{array}{l}\text { Famil- } \\
\text { iar }\end{array}$ & $\begin{array}{l}\text { Not fa- } \\
\text { miliar }\end{array}$ & $\begin{array}{l}\text { Famil- } \\
\text { iar }\end{array}$ & $\begin{array}{l}\text { Not fa- } \\
\text { miliar }\end{array}$ & $\begin{array}{l}\text { Famil- } \\
\text { iar }\end{array}$ \\
\hline \multirow{2}{*}{$\begin{array}{l}\text { Over the next } 12 \text { months in your } \\
\text { HRM business operations, do } \\
\text { you expect that your company } \\
\text { will: Introduce a new product } \\
\text { or service? }\end{array}$} & Yes & 337 & 350 & 392 & 294 & 324 & 361 \\
\hline & No & 332 & 322 & 381 & 271 & 282 & 369 \\
\hline \multirow{2}{*}{$\begin{array}{l}\text { Over the next } 12 \text { months in your } \\
\text { HRM business operations, do } \\
\text { you expect that your company } \\
\text { will: Enter a new market? }\end{array}$} & Yes & 159 & 231 & 186 & 204 & 141 & 249 \\
\hline & No & 505 & 424 & 580 & 350 & 454 & 474 \\
\hline \multirow{2}{*}{$\begin{array}{l}\text { Over the next } 12 \text { months in your } \\
\text { HRM business operations, do } \\
\text { you expect that your company } \\
\text { will: Make a major investment } \\
\text { in facilities or equipment? }\end{array}$} & Yes & 244 & 228 & 280 & 194 & 222 & 252 \\
\hline & No & 423 & 436 & 490 & 367 & 384 & 471 \\
\hline \multirow{2}{*}{$\begin{array}{l}\text { Over the next } 12 \text { months in your } \\
\text { HRM business operations, do } \\
\text { you expect that your company } \\
\text { will: Increase sales? }\end{array}$} & Yes & 527 & 542 & 620 & 448 & 477 & 587 \\
\hline & No & 122 & 127 & 129 & 119 & 111 & 139 \\
\hline \multirow{2}{*}{$\begin{array}{l}\text { Over the next } 12 \text { months in your } \\
\text { HRM business operations, do } \\
\text { you expect that your company } \\
\text { will: Hire additional staff? }\end{array}$} & Yes & 377 & 380 & 416 & 340 & 337 & 418 \\
\hline & No & 276 & 267 & 330 & 213 & 250 & 293 \\
\hline
\end{tabular}

In Table 4, the chi-square tests for GHP (Chi-square=20.294; $P<0.001$ ), for NSBI (Chi-square=24.291; $\mathrm{P}<0.001$ ), for ACOA (Chi-square=18.078; $\mathrm{P}<0.001$ ) and for ERDT (Chi-square=16.199; $\mathrm{P}<0.001$ ) reject the null hypothesis that there is no association between familiarity with key economic development organizations and the expectation to enter a new market over the next twelve months. The findings from Table 3 indicate that the proportion of the firms that expect to enter new markets is higher in the case of the firms that are familiar respectively with GHP (35.3\%), NSBI (36.8\%), ACOA (34.4\%), ERDT $(35.8 \%)$ than in the case of those that are not familiar respectively with GHP (23.9\%), NSBI (24.3\%), ACOA (23.7\%), ERDT (25.5\%). 
Table 4. Familiarity with economic development organizations and growth aspirations - Pearson Chi-Square Tests

\begin{tabular}{|c|c|c|c|c|c|}
\hline \multicolumn{6}{|c|}{ Pearson Chi-Square Tests } \\
\hline & & $\begin{array}{l}\text { Familiarity } \\
\text { with GHP }\end{array}$ & $\begin{array}{l}\text { Familiarity } \\
\text { with NSBI }\end{array}$ & $\begin{array}{l}\text { Familiarity } \\
\text { with ACOA }\end{array}$ & $\begin{array}{l}\text { Familiarity } \\
\text { with ERDT }\end{array}$ \\
\hline \multirow{3}{*}{$\begin{array}{l}\text { Over the next } 12 \text { months in your } \\
\text { HRM business operations, do } \\
\text { you expect that your company } \\
\text { will: Introduce a new product or } \\
\text { service? }\end{array}$} & Chi-square & 0.392 & 0.229 & 2.135 & 0.101 \\
\hline & Df & 1 & 1 & 1 & 1 \\
\hline & Sig. & 0.531 & 0.632 & 0.144 & 0.751 \\
\hline \multirow{3}{*}{$\begin{array}{l}\text { Over the next } 12 \text { months in your } \\
\text { HRM business operations, do you } \\
\text { expect that your company will: } \\
\text { Enter a new market? }\end{array}$} & Chi-square & 20.294 & 24.291 & 18.078 & 16.199 \\
\hline & Df & 1 & 1 & 1 & 1 \\
\hline & Sig. & $.000^{*}$ & $.000 *$ & $.000 *$ & $.000 *$ \\
\hline \multirow{3}{*}{$\begin{array}{l}\text { Over the next } 12 \text { months in your } \\
\text { HRM business operations, do } \\
\text { you expect that your company } \\
\text { will: Make a major investment in } \\
\text { facilities or equipment? }\end{array}$} & Chi-square & 0.732 & 0.45 & 0.455 & 1.693 \\
\hline & Df & 1 & 1 & 1 & 1 \\
\hline & Sig. & 0.392 & 0.502 & 0.5 & 0.193 \\
\hline \multirow{3}{*}{$\begin{array}{l}\text { Over the next } 12 \text { months in your } \\
\text { HRM business operations, do you } \\
\text { expect that your company will: } \\
\text { Increase sales? }\end{array}$} & Chi-square & 0.007 & 2.991 & 0.015 & 0.829 \\
\hline & Df & 1 & 1 & 1 & 1 \\
\hline & Sig. & 0.931 & 0.084 & 0.902 & 0.363 \\
\hline \multirow{3}{*}{$\begin{array}{l}\text { Over the next } 12 \text { months in your } \\
\text { HRM business operations, do you } \\
\text { expect that your company will: } \\
\text { Hire additional staff? }\end{array}$} & Chi-square & 0.133 & 4.269 & 0.252 & 0.426 \\
\hline & Df & 1 & 1 & 1 & 1 \\
\hline & Sig. & 0.715 & $.039 *$ & 0.616 & 0.514 \\
\hline
\end{tabular}

*. The Chi-square statistic is significant at the .05 level.

The findings from the second series of contingency tables, which focus on separate samples (sample per wave), indicate that there is no association between familiarity with key economic development organizations and the expectations to introduce a new product or service, to make a major investment in facilities or equipment and to increase sales. The results of the chi-square tests are consistent over the four waves and indicate that the null hypothesis cannot be rejected (see Tables 5, 7, 9). These results confirm the findings of the first series of contingency tables analyses.

The results displayed in Table 8 also indicate that the same conclusion is applicable to the association between familiarity and the expectation to hire additional staff except for NSBI, but only for 2013 spring wave. The results (chi-square=6.139; $\mathrm{P}<0.05$ ) reject the null hypothesis that there is no association between familiarity with NSBI and the expectation to hire more additional staff. In the 2013 spring sample, the proportion of firms that 
expect to hire additional staff is higher for the firms that are familiar with NSBI (66.1\%) than that of the firms which are not familiar with NSBI $(52.4 \%)$. The results displayed in Table 6 indicate a variation of the results for the tests of the association between familiarity with GHP, NSBI, ACOA, ERDT and the expectation to enter a new market, depending on the organization and the wave. The results from the 2013 spring wave reject the null hypothesis. On the contrary, the results from the 2011 autumn wave indicate that the null hypothesis cannot be rejected. In addition, the results from the 2012 spring wave reject the null hypothesis only for NSBI and ACOA. Finally, the results from the 2012 spring wave reject the null hypothesis only for NSBI and ERDT. We can conclude that the association between familiarity with the key economic organizations and the expectation to enter a new market is not validated over the four waves.

Table 5. Pearson Chi Square Test for the association between familiarity with business development organizations and the expectation to introduce a new product or service

\begin{tabular}{|c|c|c|c|c|c|}
\hline & & $\begin{array}{l}2011 \\
\text { Autumn }\end{array}$ & 2012 Spring & $\begin{array}{l}2012 \\
\text { Autumn }\end{array}$ & 2013 Spring \\
\hline & & \multicolumn{4}{|c|}{$\begin{array}{l}\text { Over the next } 12 \text { months in your HRM business } \\
\text { operations, do you expect that your company will: } \\
\text { Introduce a new product or service? }\end{array}$} \\
\hline \multirow{3}{*}{$\begin{array}{l}\text { Familiarity } \\
\text { with GHP }\end{array}$} & Chi-square & 1.463 & 0.337 & 0.363 & 1.449 \\
\hline & $d f$ & 1 & 1 & 1 & 1 \\
\hline & Sig. & 0.226 & 0.562 & 0.547 & 0.229 \\
\hline \multirow{3}{*}{$\begin{array}{l}\text { Familiarity } \\
\text { with NSBI }\end{array}$} & Chi-square & 2.274 & 0.747 & 1.792 & 0.002 \\
\hline & $\mathrm{df}$ & 1 & 1 & 1 & 1 \\
\hline & Sig. & 0.132 & 0.387 & 0.181 & 0.968 \\
\hline \multirow{3}{*}{$\begin{array}{l}\text { Familiarity } \\
\text { with ACOA }\end{array}$} & Chi-square & 1.064 & 0.289 & 0.506 & 0.188 \\
\hline & $d f$ & 1 & 1 & 1 & 1 \\
\hline & Sig. & 0.302 & 0.591 & 0.477 & 0.665 \\
\hline \multirow{3}{*}{$\begin{array}{l}\text { Familiarity } \\
\text { with ERDT }\end{array}$} & Chi-square & 0.013 & 0.783 & 0.508 & 0.621 \\
\hline & $\mathrm{df}$ & 1 & 1 & 1 & 1 \\
\hline & Sig. & 0.911 & 0.376 & 0.476 & 0.431 \\
\hline
\end{tabular}


Table 6. Pearson Chi Square Test for the association between familiarity with business development organizations and the expectation to enter a new market

\begin{tabular}{|c|c|c|c|c|c|}
\hline & & \multicolumn{4}{|c|}{ Wave } \\
\hline & & 2011 Autumn & 2012 Spring & 2012 Autumn & 2013 Spring \\
\hline & & \multicolumn{4}{|c|}{$\begin{array}{l}\text { Over the next } 12 \text { months in your HRM business operations, } \\
\text { do you expect that your company will: Enter a new market? }\end{array}$} \\
\hline \multirow{3}{*}{$\begin{array}{l}\text { Familiarity } \\
\text { with GHP }\end{array}$} & Chi-square & 2.405 & 3.587 & 3.765 & 13.032 \\
\hline & Df & 1 & 1 & 1 & 1 \\
\hline & Sig. & 0.121 & 0.058 & 0.052 & $.000^{*}$ \\
\hline \multirow{3}{*}{$\begin{array}{l}\text { Familiarity } \\
\text { with NSBI }\end{array}$} & Chi-square & 1.527 & 8.836 & 4.797 & 13.093 \\
\hline & Df & 1 & 1 & 1 & 1 \\
\hline & Sig. & 0.217 & $.003 *$ & $.029 *$ & $.000^{*}$ \\
\hline \multirow{3}{*}{$\begin{array}{l}\text { Familiarity } \\
\text { with ACOA }\end{array}$} & Chi-square & 1.215 & 1.854 & 7.612 & 10.685 \\
\hline & Df & 1 & 1 & 1 & 1 \\
\hline & Sig. & 0.27 & 0.173 & $.006^{*}$ & $.001^{*}$ \\
\hline \multirow{3}{*}{$\begin{array}{l}\text { Familiarity } \\
\text { with ERDT }\end{array}$} & Chi-square & 0.789 & 6.781 & 1.187 & 11.592 \\
\hline & Df & 1 & 1 & 1 & 1 \\
\hline & Sig. & 0.375 & $.009 *$ & 0.276 & $.001 *$ \\
\hline
\end{tabular}

*. The Chi-square statistic is significant at the .05 level.

Table 7. Pearson Chi Square Test for the association between familiarity with business development organizations and the expectation to increase sales

\begin{tabular}{lllll}
\hline & & \multicolumn{3}{c}{ Wave } \\
\cline { 3 - 5 } & & 2011 Autumn & 2012 Spring & 2013 Spring \\
\cline { 3 - 5 } & & \multicolumn{2}{c}{$\begin{array}{l}\text { Over the next } 12 \text { months in your HRM business } \\
\text { operations, do you expect that your company } \\
\text { will: Increase sales? }\end{array}$} \\
\hline \multirow{3}{*}{ Familiarity with GHP } & Chi-square & 0.059 & 0.244 & 0.361 \\
& df & 1 & 1 & 1 \\
& Sig. & 0.809 & 0.622 & 0.548 \\
& Chi-square & 0.757 & 0.882 & 3.918 \\
Familiarity with NSBI & df & 1 & 1 & 1 \\
& Sig. & 0.384 & 0.348 & $.048^{*}$ \\
& Chi-square & 0.913 & 2.163 & 0.014 \\
Familiarity with ERDT & df & 1 & 1 & 1 \\
& Sig. & 0.339 & 0.141 & 0.906 \\
& Chi-square & 1.422 & 0.01 & 1.015 \\
& df & 1 & 1 & 1 \\
& Sig. & 0.233 & 0.922 & 0.314 \\
\hline
\end{tabular}

*. The Chi-square statistic is significant at the .05 level. 
Table 8. Pearson Chi Square Test for the association between familiarity with business development organizations and the expectation to hire additional staff

\begin{tabular}{lllll}
\hline & & \multicolumn{3}{c}{ Wave } \\
\cline { 3 - 5 } & & 2011 Autumn & 2012 Spring & 2013 Spring \\
\cline { 3 - 5 } & & \multicolumn{2}{c}{$\begin{array}{l}\text { Over the next } \\
\text { operations, do you expect that your company } \\
\text { will: Hire Hire additional staff? }\end{array}$} \\
\hline \multirow{2}{*}{ Familiarity with GHP } & Chi-square & 0 & 0.001 & 0.686 \\
& df & 1 & 1 & 1 \\
Familiarity with NSBI & Sig. & 1 & 0.979 & 0.407 \\
& Chi-square & 0.159 & 0.839 & 6.139 \\
& df & 1 & 1 & 1 \\
Familiarity with ACOA & Sig. & 0.69 & 0.36 & $.013 *$ \\
& Chi-square & 0.117 & 0.027 & 0.002 \\
& df & 1 & 1 & 1 \\
Familiarity with ERDT & Sig. & 0.732 & 0.87 & 0.966 \\
& Chi-square & 0.002 & 0.13 & 0.173 \\
& df & 1 & 1 & 1 \\
& Sig. & 0.967 & 0.718 & 0.677 \\
\hline
\end{tabular}

*. The Chi-square statistic is significant at the .05 level.

Table 9. Pearson Chi Square Test for the association between familiarity with business development organizations and the expectation to make a major investment in facilities and equipment

\begin{tabular}{|c|c|c|c|c|c|c|}
\hline Wave & & & 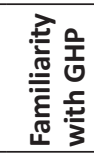 & 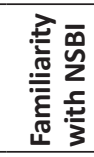 & 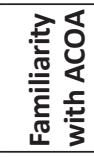 & 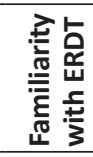 \\
\hline \multirow{3}{*}{$\begin{array}{l}2011 \\
\text { Autumn }\end{array}$} & \multirow{3}{*}{$\begin{array}{l}\text { Over the next } 12 \text { months in your HRM } \\
\text { business operations, do you expect that } \\
\text { your company will: Make a major inve- } \\
\text { stment in facilities or equipment? }\end{array}$} & Chi-s & .251 & 2.561 & .164 & .816 \\
\hline & & $\mathrm{df}$ & 1 & 1 & 1 & 1 \\
\hline & & Sig. & .616 & .110 & .686 & .366 \\
\hline \multirow{3}{*}{$\begin{array}{l}2012 \\
\text { Spring }\end{array}$} & \multirow{3}{*}{$\begin{array}{l}\text { Over the next } 12 \text { months in your HRM } \\
\text { business operations, do you expect } \\
\text { that your company will: Make a major } \\
\text { investment in facilities or equipment? }\end{array}$} & Chi-sc & .089 & .035 & .181 & .038 \\
\hline & & $\mathrm{df}$ & 1 & 1 & 1 & 1 \\
\hline & & Sig. & .766 & .852 & .671 & .846 \\
\hline \multirow{3}{*}{$\begin{array}{l}2012 \\
\text { Autumn }\end{array}$} & \multirow{3}{*}{$\begin{array}{l}\text { Over the next } 12 \text { months in your HRM } \\
\text { business operations, do you expect } \\
\text { that your company will: Make a major } \\
\text { investment in facilities or equipment? }\end{array}$} & Chi-square & .001 & .231 & .096 & 2.215 \\
\hline & & $\mathrm{df}$ & 1 & 1 & 1 & 1 \\
\hline & & Sig. & .971 & .631 & .756 & .137 \\
\hline \multirow{3}{*}{$\begin{array}{l}2013 \\
\text { Spring }\end{array}$} & \multirow{3}{*}{$\begin{array}{l}\text { Over the next } 12 \text { months in your HRM } \\
\text { business operations, do you expect } \\
\text { that your company will: Make a major } \\
\text { investment in facilities or equipment? }\end{array}$} & Chi-square & 1.016 & .044 & .037 & .154 \\
\hline & & $\mathrm{df}$ & 1 & 1 & 1 & 1 \\
\hline & & Sig. & .314 & .833 & .848 & .694 \\
\hline
\end{tabular}




\section{Logistic regression}

A binary logistic regression model was used considering the dependent variables that represent familiarity with economic development organizations (familiarity with GHP, NSBI, ACOA and ERDT) and the independent variables that represent the willingness to grow (the expectations to introduce a new product or service, to increase sales, to hire additional staff, to make a major investment in facilities or equipment and to enter a new market). The description of the variables is provided in Table 10. In Table 11, the dependent variable is 'familiarity with GHP' which comprises two categories: familiar $=1$ and Not familiar $=0$. The five independent variables representing the willingness to grow are as follows: the expectations to introduce a new product or service (Yes $=1 ; N_{0}=0$ ), to make a major investment in facilities or equipment ( $Y e s=1 ; N o=0)$, to increase sales $(Y e s=1 ; N o=0)$, to hire additional staff $(Y e s=1 ; N o=0)$, to enter a new market $(Y e s=1 ; N o=0)$.

Table 10. The description of variables

\begin{tabular}{|c|c|}
\hline Variables & Label \\
\hline \multicolumn{2}{|r|}{ Dependent variables } \\
\hline q16a & Familiarity with GHP (1='Familiar'; 0='Not Familiar') \\
\hline q16b & Familiarity with NSBI (1='Familiar'; 0='Not Familiar') \\
\hline q16c & Familiarity with ACOA (1='Familiar'; 0='Not Familiar') \\
\hline q16d & Familiarity with ERDT (1='Familiar'; 0='Not Familiar') \\
\hline \multicolumn{2}{|r|}{ Independent variables } \\
\hline q11a & $\begin{array}{l}\text { Over the next } 12 \text { months in your HRM business operations, do you expect that } \\
\text { your company will: Introduce a new product or service? ( } 1=\text { 'Yes'; } 0=\text { 'No') }\end{array}$ \\
\hline q11b & $\begin{array}{l}\text { Over the next } 12 \text { months in your HRM business operations, do you expect that } \\
\left.\text { your company will: Enter a new market? ( } 1=\text { 'Yes'; } 0=\text { ' }^{\prime} \mathrm{N}^{\prime}\right)\end{array}$ \\
\hline q11c & $\begin{array}{l}\text { Over the next } 12 \text { months in your HRM business operations, do you expect } \\
\text { that your company will: Make a major investment in facilities or equipment? } \\
\left(1={ }^{\prime} Y e s^{\prime} ; 0='{ }^{\prime} o^{\prime}\right)\end{array}$ \\
\hline q11e & $\begin{array}{l}\text { Over the next } 12 \text { months in your HRM business operations, do you expect that } \\
\left.\text { your company will: Increase sales? (1='Yes'; } 0==^{\prime} \mathrm{No}^{\prime}\right)\end{array}$ \\
\hline q11f & $\begin{array}{l}\text { Over the next } 12 \text { months in your HRM business operations, do you expect that } \\
\left.\text { your company will: Hire additional staff? ( } 1=\text { 'Yes'; } 0={ }^{\prime} \mathrm{No}^{\prime}\right)\end{array}$ \\
\hline
\end{tabular}

The same independent variables were used in the other models involving the dependent variables: 'familiarity with NSBI', 'familiarity with ACOA', 'familiarity with ERDT'. The results in Table 11 show statistical significance $(p<0.001)$ on all models for the expectation to enter a new market over the next twelve months. The $B$ coefficients indicate that the higher the expectation to enter a new market over the next twelve months, the higher the odds to be 
familiar with GHP, NSBI, ACOA and ERDT. The odd ratios tell us that businesses that do expect to enter a new market over the next twelve months are more likely to be familiar with GHP (1.69 times), NSBI (1.79 times), ACOA (1.68 times) and ERDT (1.62 times) than those that do not. The results from the logistic regression confirm the results from the tests of association that there is an association between familiarity with all key economic development organizations (GHP, NSBI, ACOA, ERDT) and the expectation to enter a new market. In addition, the findings in Table 13 indicate that businesses that do expect to introduce a new product or service over the next twelve months are significantly less likely to be familiar with ACOA than those that do not. However, these results should be taken with caution as the $\mathrm{R}^{2}$ values indicate that the models explain only between 1.3 to $2.2 \%$ of the variations.

Table 11. The binary logistic regression models for the dependence between growth aspirations and familiarity with economic development organizations

\begin{tabular}{lllllll}
\hline \multicolumn{7}{c}{ Model 1: Dependent variable: Familiarity with GHP } \\
\hline Independent variables & B & S.E. & Wald & df & Sig. & Exp(B) \\
\hline q11a(1) & -.084 & .131 & .406 & 1 & .524 & .920 \\
q11b(1) & .523 & .142 & 13.620 & 1 & .000 & 1.687 \\
q11e(1) & .050 & .166 & .093 & 1 & .761 & 1.052 \\
q11c(1) & -.154 & .135 & 1.313 & 1 & .252 & .857 \\
q11f(1) & -.013 & .140 & .009 & 1 & .926 & .987 \\
Constant & -.026 & .141 & .033 & 1 & .856 & .975 \\
Omnibus test of Model & $($ Chi-square=14.639; 5df; P<0.05) & & \\
Coefficients & 1529.923 & & & & \\
- 2 Log likelihood & .013 & & & & \\
Cox and Snell R square & \multicolumn{7}{c}{. } & & & & \\
\hline
\end{tabular}

\begin{tabular}{lllllll}
\hline \multicolumn{7}{c}{ Model 2: Dependent variable: Familiarity with NSBI } \\
\hline Independent variables & B & S.E. & Wald & df & Sig. & Exp(B) \\
q11a(1) & -.090 & .133 & .452 & 1 & .501 & .914 \\
q11b(1) & .580 & .142 & 16.721 & 1 & .000 & 1.786 \\
q11e(1) & -.395 & .167 & 5.565 & 1 & .018 & .674 \\
q11c(1) & -.213 & .137 & 2.437 & 1 & .118 & .808 \\
q11f(1) & .276 & .142 & 3.752 & 1 & .053 & 1.317 \\
Constant & -.132 & .142 & .865 & 1 & .352 & .876 \\
Omnibus test of Model & $($ Chi-square=25.070; 5df; P<0.001) & & \\
Coefficients & 1501.973 \\
- 2 Log likelihood & .022 \\
Cox and Snell R square & .07 & & & \\
\hline
\end{tabular}




\begin{tabular}{|c|c|c|c|c|c|c|}
\hline \multicolumn{7}{|c|}{ Model 3: Dependent variable: Familiarity with ACOA } \\
\hline Independent variables & B & S.E. & Wald & df & Sig. & $\operatorname{Exp}(B)$ \\
\hline q11a(1) & -.296 & .133 & 4.983 & 1 & .026 & .744 \\
\hline$q 11 b(1)$ & .516 & .143 & 12.926 & 1 & .000 & 1.675 \\
\hline q11e(1) & .012 & .167 & .005 & 1 & .942 & 1.012 \\
\hline$q 11 c(1)$ & -.150 & .136 & 1.228 & 1 & .268 & .860 \\
\hline$q 11 f(1)$ & .050 & .141 & .128 & 1 & .720 & 1.052 \\
\hline Constant & .241 & .142 & 2.884 & 1 & .089 & 1.272 \\
\hline $\begin{array}{l}\text { Omnibus test of Model } \\
\text { Coefficients }\end{array}$ & \multicolumn{6}{|c|}{ (Chi-square $=15.620 ; 5 d f ; P<0.01$ ) } \\
\hline - 2 Log likelihood & \multicolumn{6}{|c|}{1510.890} \\
\hline Cox and Snell R square & \multicolumn{6}{|l|}{.014} \\
\hline \multicolumn{7}{|c|}{ Model 4: Dependent variable: Familiarity with ERDT } \\
\hline Independent variables & B & S.E. & Wald & Df & Sig. & $\operatorname{Exp}(B)$ \\
\hline $\mathrm{q} 11 \mathrm{a}(1)$ & -.160 & .134 & 1.426 & 1 & .232 & .852 \\
\hline$q 11 b(1)$ & .476 & .142 & 11.247 & 1 & .001 & 1.610 \\
\hline q11e(1) & .207 & .171 & 1.461 & 1 & .227 & 1.230 \\
\hline $\mathrm{q} 11 \mathrm{c}(1)$ & .121 & .137 & .781 & 1 & .377 & 1.128 \\
\hline$q 11 f(1)$ & -.115 & .143 & .646 & 1 & .422 & .892 \\
\hline Constant & -.627 & .147 & 18.282 & 1 & .000 & .534 \\
\hline $\begin{array}{l}\text { Omnibus test of Model } \\
\text { Coefficients }\end{array}$ & \multicolumn{6}{|c|}{ (Chi-square=14.970; 5df; $P<0.05$ ) } \\
\hline - 2 Log likelihood & \multicolumn{6}{|c|}{1484.264} \\
\hline Cox and Snell R square & \multicolumn{6}{|l|}{.013} \\
\hline
\end{tabular}

\section{DISCUSSION AND CONCLUSIONS}

In this preliminary stage of a broader research project about the process of small business growth, the main research question is: Does entrepreneur's willingness to grow affect familiarity with key actors in the entrepreneurial ecosystem such as the key economic development organizations? To investigate this research question, we focused on the case study of Halifax Regional Municipality in Nova Scotia (Canada), where the four key economic development organizations are GHP, NSBI, ERDT and ACOA. Firstly, we started with investigating the association between the variables of interest. Secondly, we investigated the effect of the willingness to grow on familiarity with the key economic development organizations. Our analyses show, in general, that there is a relationship between familiarity with the key economic development organizations such as GHP, NSBI, ACOA, and ERDT and the willingness to grow. However, these results are not valid for all the variables 
that we considered as measures of the willingness to grow. In addition, the results are not homogeneous across the waves.

The findings provide support for the relationship between familiarity with a key economic organization and the expectation to hire additional staff or enter new markets within the next twelve months. The findings also support the assumption that the proportion of businesses that expect to hire additional staff within the next twelve months is higher for the group of businesses that are familiar with NSBI. The functions identified for Nova Scotia Business Incorporated (NSBI) consist of business advisory services and financial support for market expansion. The business advisory services include support for hiring by connecting businesses with partners or consultants and providing funding support through NSBI payroll rebate program. Although the results are not homogeneous across all waves, the findings indicate that the proportion of businesses that expect to enter new markets within the next twelve months is higher for the group of businesses that are familiar with GHP or NSBI or ACOA or ERDT. In addition, the higher the expectation to enter a new market over the next twelve months, the higher the odds to be familiar with GHP, NSBI, ACOA and ERDT. All four organizations provide business support services for market expansion through their functions in the entrepreneurial ecosystem.

The findings suggest that the entrepreneur' networking behavior may be affected by the business growth strategies. Therefore, the research questions that emerge from the findings are: What business support services are the most effective to stimulate small business growth? How does the entrepreneur's network evolve throughout the growth process? These are questions that we intend to investigate further. The results also indicate that a substantial proportion of businesses are still unaware of the resources that are available through the key economic development organizations. The findings have implications for the key economic development organizations. The managers of the economic development organizations need to find more efficient ways to raise awareness about their functions in the entrepreneurial ecosystem. In addition, our findings inform public policy makers about the type of business supports services that are related to small business growth.

As already stated in the research method section, this study has its limitations. However, our findings are consistent with the results from previous empirical studies as they confirm the relationship between networking and small business growth (Hansen \& Hamilton, 2011; Larson, 1992; Watson, 2007). Hansen and Hamilton (2011) investigated the factors that differentiate growers from non-growers. They found that the use of private business networks is one of the factors that differentiate the two groups. The owner managers of the growth businesses see more value in networking than the 
owner managers of the non-growth businesses. Watson (2007) examined the impact of personal networks on firm performance, especially for established businesses, and found a significant association between formal networks and small business growth. However, the informal relationships have been found to be more effective in network dyads (Larson, 1992). Small business owners are able to gain access to the external resources for growth as long as they are able to develop the adequate relationships with the relevant actors. In our study, we found a significant association between "familiarity with NSBI" and the small business owner's expectations to hire additional staff. Similarly, our findings indicate that the higher the expectation to enter a new market over the next twelve months, the higher the odds for the small business owner to be familiar with GHP, NSBI, ACOA and ERDT. Considering that NSBI provides advisory services for hiring and that all four economic development organizations provide business support services for market expansion then, it is reasonable to expect that small businesses owners will more likely develop relationships with the actors in the entrepreneurial ecosystem that meet their needs for growth.

Future research using a comparative analysis of different geographic locations may contribute to investigate the relationship between the entrepreneur's familiarity with the economic development organizations of the entrepreneurship ecosystem and the willingness to grow.

\section{Acknowledgements}

The author would like to thank the Greater Halifax Partnership for providing access to the dataset used in this research. The content of this publication is solely the responsibility of the author.

\section{References}

Agresti, A. \& Kateri, M. (2011). Categorical data analysis. Berlin-Heidelberg: Springer.

Anderson, A. R., Dodd, S. D. \& Jack, S. (2010). Network practices and entrepreneurial growth. Scandinavian Journal of Management, 26(2), 121-133.

Atlantic Canada Opportunities Agency (ACOA). Retrieved November 9, 2015, from http://www.acoa-apeca.gc.ca/eng/ImLookingFor/ ProgramInformation/Pages/Home.aspx

Barkham, R., Gudgin, G. \& Hanvey, E. (1996). Determinants of small firm growth: An inter-regional study in the United Kingdom 1986-90. Gateshead: Athenaeum Press. 
Baum, J. R. \& Locke, E. A. (2004). The relationship of entrepreneurial traits, skill, and motivation to subsequent venture growth. Journal of Applied Psychology, 89(4), 587.

Becchetti, L., \& Trovato, G. (2002). The determinants of growth for small and medium sized firms. the role of the availability of external finance. Small Business Economics, 19(4), 291-306.

Birch, D. G. (1987). Job creation in America: how our smallest companies put the most people to work. University of Illinois at Urbana-Champaign's Academy for Entrepreneurial Leadership Historical Research Reference in Entrepreneurship, Available at SSRN: http://ssrn.com/abstract $=1496185$

Birley, S. \& Stockley, S. (2000). Entrepreneurial teams and venture growth. In Sexton, D.L. (Ed.). The Blackwell handbook of entrepreneurship (pp. 287307). Oxford: Blackwell.

Chandler, G. N. \& Hanks, S. H. (1994). Founder competence, the environment and venture performance. Entrepreneurship Theory and Practice, 18, 7777.

Chandler, G. N., \& Jansen, E. (1992). The founder's self-assessed competence and venture performance. Journal of Business Venturing, 7(3), 223-236.

Cohen, B. (2006). Sustainable valley entrepreneurial ecosystems. Business Strategy and the Environment, 15(1), 1-14.

Conover, W. J. (1980). Practical nonparametric statistics, $2^{\text {nd }}$ edition, Wiley.

Cooper, A. C., Gimeno-Gascon, F. J. \& Woo, C. Y. (1994). Initial human and financial capital as predictors of new venture performance. Journal of Business Venturing, 9(5), 371-395.

Davidsson, P. (1989). Entrepreneurship-and after? A study of growth willingness in small firms. Journal of Business Venturing, 4(3), 211-226.

Davidsson, P. (1991). Continued entrepreneurship: Ability, need, and opportunity as determinants of small firm growth. Journal of Business Venturing, 6(6), 405-429.

Davidsson, P., Achtenhagen, L., \& Naldi, L. (2005). Research on small firm growth: a review. European Institute of Small Business. Retrieved from http://eprints.qut.edu.au/2072/

Davidsson, P., \& Wiklund, J. (2013). New perspectives on firm growth. Edward Elgar Publishing.

Davidsson, P. (1989). Entrepreneurship-and after? A study of growth willingness in small firms. Journal of Business Venturing, 4(3), 211-226.

Garnsey, E. (1998). A theory of the early growth of the firm. Industrial and Corporate Change, 7(3), 523-556.

Gundry, L. K., \& Welsch, H. P. (1997). The ambitious entrepreneur: Attributes of firms exhibiting high growth strategies. Frontiers of Entrepreneurship, Retrieved from http://fusionmx.babson.edu/entrep/fer/papers97/ gundry/Gun.htm

Halifax Partnership. Business plan 2015-2016. Retrieved November 9, 2015, from http://www.halifaxpartnership.com/site/media/ 
Parent/2015-16\%20Business\%20Plan\%20-\%20Low\%20Rez\%20 -FINAL\%20-\%20May\%208\%202015.pdf

Hansen, B., \& Hamilton, R. T. (2011). Factors distinguishing small firm growers and non-growers. International Small Business Journal, 29(3), 278-294.

Isenberg, D. J. (2010). How to start an entrepreneurial revolution. Harvard Business Review, 88(6), 40-50.

Jarillo, J. C. (1989). Entrepreneurship and growth: the strategic use of external resources. Journal of Business Venturing, 4(2), 133-147.

Kimberely, Miles, J. (1980). The organizational life cycle. San Francisco: Jossey-Bass.

Kolvereid, L. (1992). Growth aspirations among Norwegian entrepreneurs. Journal of Business Venturing, 7(3), 209-222.

Larson, A. (1992). Network dyads in entrepreneurial settings: s study of the governance of exchange relationships. Administrative Science Quarterly, 37(1), 76-104.

Mason, C., \& Brown, R. (2014). Entrepreneurial ecosystems and growth oriented entrepreneurship - Final Report Paris: OECD, Retrievied from http://www.oecd.org/fr/cfe/leed/entrepreneurialecosystemsandgrow th-orientedentrepreneurshipworkshop-netherlands.htm

McKelvie, A., \& Wiklund, J. (2010). Advancing firm growth research: a focus on growth mode instead of growth rate. Entrepreneurship Theory and Practice, 34(2), 261-288.

Neck, H. M., Meyer, G. D., Cohen, B. \& Corbett, A. C. (2004). An entrepreneurial system view of new venture creation. Journal of Small Business Management, 42(2), 190-208.

Pfeffer, J., \& Salancik, G. (1978). The external control of organizations: a resource dependence perspective. NY: Harper \& Row.

Province of Nova Scotia. Department of economic and rural development and tourism: statement of mandate 2014-2015. Retrieved November 9, 2015, from http://novascotia.ca/government/accountability/2014-2015-ERDTStatement-of-Mandate.pdf

Province of Nova Scotia. (2015). Budget 2015-2016: Crown Corporation Business Plans. Retrieved November 9, 2015, from http://www. novascotia.ca/finance/site-finance/media/finance/budget2015/Crown_ Corp_Business_Plans.pdf

Širec, K., \& Bradač, B. (2009). How does networking impact the SMEs growth. Organizacija, 42(2), 59-66.

Spilling, O. R. (1996). The entrepreneurial system: on entrepreneurship in the context of a mega-event. Journal of Business Research, 36(1), 91-103.

Storey, D. J., Watson, R. \& Wynarczyk, P. (1989). Fast growth small businesses: case studies of 40 small firms in North East England. London: Department of Employment. Research Paper Series No 67.

Storey, D. J. (1994). Understanding the small business sector. University of Illinois at Urbana-Champaign's Academy for Entrepreneurial Leadership 
Historical Research Reference in Entrepreneurship, Available at SSRN: http://ssrn.com/abstract $=1496214$

Vogel, P. (2013). The employment outlook for youth: building entrepreneurship ecosystems as a way forward. In Conference Proceedings of the G2O Youth Forum.

Watson, J. (2007). Modeling the relationship between networking and firm performance. Journal of Business Venturing, 22(6), 852-874.

\section{Abstrakt (in Polish)}

Celem artykułu jest zbadanie relacji między tworzeniem powiqzań sieciowych $i$ aspiracjami wzrostowymi. Przedstawione badanie koncentruje się szczególnie na określeniu zwiqzku między znajomościq kluczowych organizacji wspierajq̨cych rozwój gospodarczy w ramach ekosystemu przedsiębiorczości i dqżeniem do wzrostu. Istnieje znaczny dorobek badań na temat ekspansji małych i średnich przedsiębiorstw (MSP), ze względu na znaczenie szybko rosnqcych MSP dla wzrostu gospodarczego poprzez tworzenie miejsc pracy. W ramach tych badań określono wiele wewnętrznych $i$ zewnętrznych determinantów wpływajq̨cych na wzrost małych firm. Stwierdzono, że takie cechy przedsiębiorców jak dqżenie do wzrostu i działanie w ramach sieci stanowiq istotne czynniki $w$ procesie ekspansji. Jednak relacja między procesem wzrostu i działaniem przedsiębiorcy w ramach sieci wymaga pełniejszego zrozumienia. Odwołując się do literatury z zakresu ekosystemu przedsiębiorczości, procesu wzrostu i teorii zależności zasobów, w badaniu zanalizowano wyniki sondażu skierowanego do przedsiębiorstw $w$ regionie Halifax w Nowej Szkocji na terenie Kanady, w latach 2011-2013. Celem badania było określenie relacji między dqżeniem przedsiębiorcy do wzrostu i skłonnościq do powiqzań sieciowych z kluczowymi organizacjami wspierajq̨cymi rozwój gospodarczy w ekosystemie przedsiębiorczości. Wyniki potwierdzajq założenie, że frakcja przedsiębiorstw, które dq̨żq do wzrostu (tj. do zatrudnienia dodatkowego personelu i wejścia na nowe rynki w ciqgu kolejnych 12 miesięcy) jest większa w przypadku przedsiębiorstw wykazujqcych się znajomościq organizacji wspierajqcych rozwój gospodarczy, niż w przypadku przedsiębiorstw, które nie wykazujq się tq znajomościq. Rezultaty nie sq jednak jednolite w całej populacji. Wyniki wskazuja ponadto, że im wyższe oczekiwania co do wejścia na nowe rynki w ciaggu kolejnych 12 miesięcy, tym większe szanse, że przedsiębiorca wykaże się znajomościq kluczowych organizacji rozwoju gospodarczego. Rezultaty badań stanowiq wkład do literatury na temat zwiqzków między powiq̨zaniami sieciowymi i wzrostem małych przedsiębiorstw.

Słowa kluczowe: proces wzrostu, mała firma, ekosystem przedsiębiorczości, powiqzania sieciowe, Kanada. 


\section{Biographical note}

Angelo Dossou-Yovo is an Assistant Professor of Entrepreneurship and Innovation at the Rowe School of Business, Dalhousie University. He received his Ph.D. in Management at the University of Quebec in Montreal (Quebec) in 2011. His research interests include the growth process of small businesses, the innovation process of small businesses in the high technology industry, innovation systems and entrepreneurial ecosystem. 